\title{
The Corporate Responsibility for Human Rights: A Conceptual Framework
}

\author{
Linda Muswaka \\ Lecturer, Faculty of Law, North West University, South Africa \\ E-mail: leemuswaka@gmail.com
}

\section{Doi:10.5901/mjss.2014.v5n3p219}

\begin{abstract}
In this modern society, the traditional concept by which only States and individuals can be held responsible for abuses of human rights is being called into question. There is an increasingly prominent debate emerging around business and human rights. This article contributes to this debate by analyzing, from a South African perspective, the extent to which international and national human rights law is applicable to companies. It will be argued that the greatest challenge for companies willing to carry out their human rights responsibilities is the great complexity of the issues involved. For instance, while the business activities of companies can impact human rights in numerous, often interconnected ways, the scope of company responsibility, both legally and with regard to stakeholders' expectations, has so far not been defined precisely. This article therefore, seeks to make a contribution in this regard. The rationale being that companies are likely to face increasing expectations, pressures, and incentives for enhanced due diligence on human rights. This is premised on international policy trends and South African political and legal developments.
\end{abstract}

Keywords: Good Corporate Citizenship, Companies, Human Rights, Stakeholders

\section{Introduction}

Companies, as corporate citizens, have a responsibility for human rights. However, an argument that can be presented against incorporating human rights into business is that human rights are the concern and responsibility of States, not companies. It is submitted that while the primary responsibility for human rights does lie with States, companies are not exempt from responsibility. This responsibility exists independently of States' abilities and or willingness to fulfill their human rights obligations. Hence, a State's failure to implement international human rights obligations or the fact that it may act contrary to international obligations does not diminish the expectation that companies respect human rights. In fact, in countries where domestic laws and regulations conflict with internationally recognized human rights, companies should seek ways to honour them to the fullest extent which does not place them in violation of domestic law

This article analyses, from a South African perspective, the extent to which international and national human rights law is applicable to companies. It will be argued that the greatest challenge for companies willing to carry out their human rights responsibilities is the great complexity of the issues involved. For instance, while the business activities of companies can impact human rights in numerous, often interconnected ways, the scope of company responsibility, both legally and with regard to stakeholders' expectations, has so far not been defined precisely. This article therefore, seeks to make a contribution in this regard. The rationale being that companies are likely to face increasing expectations, pressures, and incentives for enhanced due diligence on human rights. This is premised on international policy trends and South African political and legal developments. There is also an emerging understanding of the business value of human rights as a framework for adopting a strategic approach to corporate responsibility.

\section{Brief Overview of Human Rights}

Formalized human rights have been with us for almost 800 years, starting with the English Magna Carta of 1215. The Universal Declaration of Human Rights was adopted in 1948, with its preamble stating that "recognition of the inherent dignity and of the equal and inalienable rights of all members of the human family is the foundation of freedom, justice and peace in the world". Article 1 of the Universal Declaration emphasizes the universal nature of human rights: "All human beings are born free and equal in dignity and rights." Article 2 focuses on nondiscrimination: "Everyone is entitled to all the rights and freedoms set forth in this Declaration, without distinction of any kind." Articles 3 to 30 define the various fundamental rights, ranging from the "right to life, liberty, and security of a person" to the right to "participate in 
the cultural life of the community". The Universal Declaration is not formally binding, but it does provide the basis for two binding human rights treaties, namely, the International Covenant on Civil and Political Rights ${ }^{1}$ and the International Covenant on Economic, Social, and Cultural Rights. ${ }^{2}$ Together these three documents are referred to as the International Bill of Human Rights. In addition to the International Bill of Rights, there is a wide array of other international and regional human rights treaties. Also important, among others are the labour standards of the International Labor Organization. ${ }^{3}$ Regional initiatives include the African Charter on Human and Peoples' Rights, ${ }^{4}$ adopted in 1979 by the Organization of African Unity. The South African Constitution is notable for the extent to which it includes in its Bill of Rights both categories of civil and political and socio-economic rights.

\section{Corporate Responsibilities for Human Rights: Binding or Voluntary}

The following discussion seeks to determine whether or not companies registered in South Africa are the subject of binding responsibilities for human rights protection. It is argued that the notion that corporate responsibilities for human rights are assumed voluntarily is fundamentally flawed. Having rights entails that others have a duty not to violate those rights, and the notion of having a duty in turn means that the course of action concerned is obligatory, not voluntary. This means that duties to fulfill human rights cannot be voluntary. If companies have such duties, then they must be binding. If they lack these duties, then we must accept that they have discretion whether to adopt certain courses of action we may regard as good, but such actions cannot be required. It is thus critical to clarify whether or not corporations are the subject of binding responsibilities for human rights protection. In this regard, some of the sources of the expectations on companies to consider human rights in corporate governance are outlined below.

\subsection{The Companies Act 71 of 2008}

The Companies Act does not contain an explicit duty of directors to consider stakeholders' interests. The duty to consider stakeholders' interests would automatically include the duty to respect human rights. In the absence of a duty to consider stakeholders' interests, one may argue that directors are not required to consider human rights when managing their companies. However, section 7(a) states that one of the purposes of the Companies Act is 'to promote compliance with the Bill of Rights.' In this light, it is argued that the Companies Act albeit indirectly requires, directors in the management of their companies, to respect recognized fundamental human rights. It is noted that outside of the company law, companies have independent legal duties to comply with inter alia labour rights laws, health law and environmental law all of which ultimately impact on human rights.

\subsection{The Constitution of the Republic of South Africa, 1996}

The Bill of Rights as provided for in the Constitution has brought about a significant shift in society's moral perception of companies. ${ }^{5}$ This is as a result of section 8 of the Constitution which imposes responsibilities upon individuals and juristic persons for the realisation of human rights. The notion of creating a company pursuing shareholder wealth maximization at the expense of human rights is therefore, legally untenable as the Bill of Rights applies to companies in a manner that goes beyond mere financial considerations. The responsibilities outlined in the Bill of Rights provide the framework within which companies must legally operate. It is submitted that the horizontal application of the Bill of Rights to companies brings about a shift in the very nature of the company that requires concomitant company law reform.

\subsection{The King Report on Corporate Governance for South Africa 2009}

The King Report on Corporate Governance for South Africa 2009, ${ }^{6}$ which operates on an 'apply or explain' basis, recommends that companies should respect and realize universally recognized fundamental human rights. According to

\footnotetext{
${ }^{1}$ Hereafter, ICCPR.

${ }^{2}$ Hereafter, ICESCR.

${ }^{3}$ Hereafter, ILO.

${ }^{4}$ Hereafter, ACHPR.

${ }^{5}$ It is now generally accepted that companies has an important role to play, not only in the economy, but also in responding to economic, social and environmental challenges.

${ }^{6}$ Hereafter, King III.
} 
King III, ${ }^{7}$ in order "to realize human rights in any society, companies should respect and recognize the basic interests of individuals and communities by creating and sustaining conditions in which human potential can develop." King III goes further to state that this entails liberating people from unfair discrimination and empowering them to take control of their own lives through for example, access to education, health care and other resources. ${ }^{8}$

\subsection{International Law}

International law ${ }^{9}$ requires companies to address human rights. International law is relevant because it has both a direct and indirect impact on law and policy-making in South Africa. Section 39 of the Constitution, obliges a court to consider international law as a tool of interpretation of the Bill of Rights. It is worth noting that the international law that must be considered in interpreting the Bill of Rights refers to both binding and non-binding international law as clearly articulated in the case of $S v$ Makwanyane..$^{10}$ In this case, the court emphasized that international law is important and should be considered in interpreting the Bill of Rights since it provides a framework in which we understand the Bill of Rights. ${ }^{11}$ However, although the Courts must take into consideration international law when interpreting constitutional provisions, the weight of international law and principles recognized will vary on a case by case basis as highlighted in Government of the Republic of South Africa $v$ Grootboom. ${ }^{12}$ Section 231 of the Constitution is also important in highlighting the role of international law in South Africa. The section provides that a treaty binds South Africa after approval by the National Assembly and the National Council of Provinces, unless it is self executing, ${ }^{13}$ or of a technical, administrative or executive nature. Furthermore, in terms of section 232, the Constitution also makes international customary law part of the law of South Africa unless it is in contradiction with constitutional provisions or legislation. In section 233, the Constitution states that when interpreting any legislation the approach that is consistent with international law is more preferable to that which contradicts it.

As the courts are obliged to consider both binding and non-binding international law when interpreting the Bill of Rights, the following discussion will highlight both the hard and soft law dealing with the corporate duty to respect human rights. It is noteworthy that while there are various international instruments that address the corporate duty to respect human rights, only a select few will be discussed. These are the following:

\subsubsection{The International Bill of Rights}

An authoritative list of the core internationally recognized human rights is contained in the International Bill of Human Rights (consisting of the Universal Declaration of Human Rights and the main instruments through which it has been codified: the ICCPR and the ICESCR). The preamble of the Universal Declaration of Human Rights calls on 'every individual and every organ of society' to promote and respect human rights. Henkin notes that 'every individual and every organ of society excludes no one, no company, no market, no cyberspace. ${ }^{14}$ Companies, as specialized organs of society performing specialized functions, are therefore required to respect human rights.

\footnotetext{
7 See King III 22.

${ }^{8}$ lbid.

9 International law is a combination of treaties and customs that regulate the conduct of states amongst themselves. International law has three main sources, namely, customary international law, treaty law and soft law. Customary international law comes from the customs practiced over a long period of time by various states. These customs are often not written in treaties or legislation, but have become an international standard that governments must follow. Soft law refers to all sources of non-binding international law that can provide guidance on the interpretation of international treaties. Treaty law is based on the agreement of states signing and ratifying the treaty.

10 S v Makwanyane 1995 (3) SA 391 (CC) para 35.

${ }^{11} \mathrm{lbid}$.

12 Government of the Republic of South Africa v Grootboom 2001 (1) SA 46 para 26.

${ }^{13} \mathrm{~A}$ self-executing treaty has a provision stating that it is self-executing. It becomes law in South Africa when it is signed unless if it is inconsistent with the Constitution or an Act. A non self- executing treaty that has not been ratified or even signed, will bind South Africa only if it becomes customary international law.

${ }^{14}$ Henkin L, "The Universal Declaration at 50 and the Challenge of Global Markets," (1999) 25(1) Brooklyn Journal of International Law 25.
} 


\subsubsection{The Guiding Principles on Business and Human Rights}

Another important international law instrument is the Guiding Principles on Business and Human Rights: Implementing the United Nations 'Protect, Respect and Remedy' Framework ${ }^{15}$ which was endorsed by the UN Human Rights Council on 11 June 2011 as a new set of guiding principles for global business designed to provide a global standard for preventing and addressing the risk of adverse impacts on human rights linked to business activity. This endorsement was preceded by an earlier unsuccessful attempt by a Sub-Commission of the then UN Commission on Human Rights to win approval for a set of binding corporate human rights norms, the so called "Norms on the Responsibilities of Transnational Corporations and Other Business Enterprises with Regard to Human Rights." The Guiding Principles on Business and Human Rights contains three types of principles namely, those focusing on (i) the State duty to protect human rights; (ii) the corporate responsibility to respect human rights; and (iii) access to remedy. These Guiding Principles apply to all States and to all business enterprises, both transnational and others, regardless of their size, sector, location, ownership and structure. ${ }^{16}$

\subsubsection{The OECD Guidelines for Multinational Enterprises}

In 1976, the Organization for Economic Co-operation and Development ${ }^{17}$ passed the OECD Guidelines for Multinational Enterprises ${ }^{18}$ of which the 2011 edition is the most recent version. ${ }^{19}$ The OECD Guidelines are recommendations jointly addressed by governments to multinational enterprises. They provide principles and standards of good practice consistent with applicable laws and internationally recognized standards. It is however, noteworthy that OECD Principles are non-binding and are not prescriptive. ${ }^{20}$ Their rationale is to operate as a basic reference point. ${ }^{21}$ The OECD Principles were created in order to support member and non-member states ${ }^{22}$ in the evaluation and improvement of the legal, institutional and regulatory structure for corporate governance in their countries.

The OECD Guidelines for instance, inter alia state that enterprises should, within the framework of internationally recognized human rights, the international human rights obligations of the countries in which they operate as well as relevant domestic laws and regulations, inter alia (i) respect human rights, which means they should avoid infringing on the human rights of others and should address adverse human rights impacts with which they are involved; (ii) Within the context of their own activities, avoid causing or contributing to adverse human rights impacts and address such impacts when they occur; and (iii) Have a policy commitment to respect human rights.

\subsubsection{The International Labour Organization Tripartite Declaration}

In 1977, the International Labour Organization's ${ }^{23}$ governing body, comprising governments, employers and workers approved the Tripartite Declaration of Principles concerning Multinational Enterprises. The Tripartite Declaration is nonbinding and relates primarily to labour matters, including health and safety, a minimum age of employment, and

\footnotetext{
${ }^{15}$ See Guiding Principles and Human Rights; Implementing the United Nations 'Protect, Respect and Remedy' Framework 2011, (hereafter, the Guiding Principles and Human Rights) available at http://www.ohchr.org/Documents/Publications/GuidingPrinciples BusinessHR_En.pdf, accessed on 10 January 2013.

${ }^{16}$ See the Guiding Principles and Human Rights) available at http://www.ohchr.org/Documents/Publications/GuidingPrinciplesBusiness HR_En.pdf, accessed on 10 January 2013.

17 Hereafter, the OECD.

${ }_{18}$ Hereafter, the OECD Guidelines.

19 See OECD Guidelines 2011, available at http://www.oecd.org/daf/inv/mne/48004323.pdf, accessed on 10 January 2013.

${ }^{2}$ Nevertheless, some matters covered by the Guidelines may also be regulated by national law or international commitments. For criticism of the voluntary nature of the OECD Guidelines see among others, Chirwa, D.M "The Long March to Binding Obligations of Transnational Corporations in International Human Rights Law" 2006 SAJHR vol. 22, 84-85.

${ }^{21}$ Preamble to the 'OECD Principles of Corporate Governance,' 2004. Accessed on 26 July 2011. Available at http://www.oecd.org/daf /corporateaffairs/corporategovernance.

22 It is worth noting that South Africa is one of the many non-member economies with which the OECD has working relations in addition to its member states. On 16 May 2007, the OECD Council at Ministerial level adopted a Resolution on Enlargement and Enhanced Engagement to strengthen the co-operation with South Africa, as well as with Brazil, China, India and Indonesia through a programme of enhanced engagement. The OECD Council Resolution on Enlargement and Enhanced Engagement, accessed on 14 May 2012 is available at http://www.oecd.org/brazil/oecdcouncilresolutiononenlargementandenhancedengagement.htm.

${ }^{23}$ Hereafter, the ILO.
} 
conditions and benefits of work, among others. Parties concerned with the Tripartite Declaration also bind themselves to respect the Universal Declaration of Human Rights and corresponding International Covenants ${ }^{24}$ as well as the Constitution of the ILO. The Tripartite Declaration is a significant recognition by business of its obligations to respect human rights.

\subsubsection{The United Nations Global Compact}

The United Nations Global Compact ${ }^{25}$ is a voluntary initiative for aligning companies' strategies and operations with ten universally accepted principles in the areas of human rights labour rights, environmental responsibility and anticorruption. The human rights principles states that companies should: (i) support and respect the protection of internationally proclaimed human rights; ${ }^{26}$ and (ii) ensure that they are not complicit ${ }^{27}$ in human rights abuses. ${ }^{28}$ The objective of the Compact is to place the ten principles at the centre of business activities around the world.

\section{The Content of the Corporate Responsibility for Human Rights}

While the above discussion has highlighted that companies have a binding responsibility for human rights, it is submitted that the greatest challenge for companies willing to carry out their human rights responsibility is the great complexity of the issues involved. For instance, while the business activities of companies can impact human rights in numerous, often interconnected ways, the scope of company responsibility, both legally and with regard to stakeholders' expectations, has so far not been defined precisely.

It is argued that the scope of the corporate responsibility for human rights must be viewed in the context of section 7 of the Constitution. Section 7 obliges the State to respect, protect, promote and fulfil the rights in the Bill of Rights. Therefore, borrowing from the wording of section 7 , it is submitted that the corporate obligation for human rights entails that companies must respect, protect, promote and fulfil human rights. The primary responsibility for the realisation of human rights, however, remains with the State. Furthermore, the corporate responsibilities for human rights do not diminish the State's responsibility for the realisation of human rights.

The duty to respect human rights means that companies should avoid infringing on the human rights of others and should address adverse human rights impacts with which they are involved. In other words, companies should avoid causing or contributing to adverse human rights impacts through their own activities and address such impacts when they occur. ${ }^{29}$

The duty to protect human rights inter alia entails that where a company may cause an adverse human rights impact, it should take the necessary steps to prevent the impact. Where a company may contribute to such an impact, it should take the necessary steps to prevent its contribution. Furthermore, the duty entails that companies should avoid being complicity in human rights.

The duty to promote human rights requires companies to create awareness among the citizenry about their rights, their remedies and how best to secure their freedoms. This may involve companies enlightening stakeholders such as employees on the laws affecting them. Furthermore, promoting human rights may also involve providing housing for their employees and building schools and hospitals in the communities in which they carry on business.

The duty to fulfill human rights entails that where all circumstances show the distress of individuals in meeting the necessities for human survival, companies should exert measures to offer assistance as much as they are practically able to afford. However, it is noteworthy that while the horizontal application of the Bill of Rights to companies is a relatively well defined principle in constitutional law, especially with regard to civil and political rights, this relationship is less clear with regard to socio-economic rights. The courts are therefore, likely to apply the 'standard of reasonableness' when assessing whether in a particular situation, it can be reasonably expected for a company to fulfill duties in support

\footnotetext{
24 The ICCPR and the ICESCR.

${ }_{25}$ The United Nations Global Compact, (hereafter, the UN Global Compact) available at http://www.unglobalcompact.org/AboutTheGC /TheTenPrinciples/ accessed on 18 March 2013.

${ }^{26}$ See the UN Global Compact Principle 1.

${ }^{27}$ Corporate complicity in human rights violations refers to indirect involvement by a company in abuses carried out by a government or other actors. Charges of complicity can be raised when a company knew, or should have reasonably known, of its contribution to the human rights abuse.

28 See the UN Global Compact Principle 2.

${ }^{29}$ It is note worthy that 'activities' includes both actions and omissions.
} 
of the progressive realization of individuals' socio-economic rights.

Having determined the scope of the corporate responsibilities for human rights, a matter of concern that arises for determination is which human rights companies should be responsible for. While one might argue that companies should be responsible for human rights within their 'sphere of influence,' this concept has so far not been clearly defined and is therefore somewhat difficult in legal terms. The better approach appears to be that since companies can have an impact on virtually the entire spectrum of recognized human rights, their responsibilities applies to all such rights. In practice, some human rights may be at greater risk than others in particular industries or contexts, and therefore will be the focus of heightened attention. However, situations may change, so all human rights should be the subject of periodic review.

\section{Stakeholder Oriented Corporate Governance}

A company's execution of responsibilities for human rights may be impeded by the fact that human rights might conflict between different stakeholders. Furthermore, the presence of business can also have important impact on the wider political context, for example when collaboration morally supports or even provides financial means to oppressive regimes. A particularly important issue for companies is the risk of complicity in human rights violations. It is submitted that a stakeholder oriented corporate governance approach that allows companies to understand the scope of their human rights obligations and adequately deal with the dilemmas involved is crucial.

Stakeholder oriented corporate governance entails that companies through human rights impact assessments, identify and engage stakeholders impacted by their actions before making a decision and after carrying out the objectives of the decision. Through the human rights impact assessments, directors are sensitized to see the impact of their decisions from the perspective of those stakeholders whom the company affects. Consequently, they will then seek ways to prevent or mitigate adverse human rights impacts that are directly linked to their business operations having due regard to inter alia the nature of the country in which their business activities take place and any specific human rights challenges these may pose as well as the human rights impacts which their own activities may have in that country.

Given that it may be virtually difficult or impossible for companies to satisfy all stakeholders to the extent of their expectations, directors should, through a stakeholder oriented corporate governance, trade off their choices so that potential disappointments on the part of any stakeholder would not arise or at least each stakeholder may be convinced on the choices of directors' decisions by understanding directors' realistic inability to satisfy their hundred percent expectations.

\section{Conclusion}

The growing demand on companies to base their decisions and operations on the satisfaction of stakeholders' interests has paved the way for the need to consider human rights when making strategic decisions. This is not surprising given that in this modern society, the traditional concept by which only States and individuals can be held responsible for abuses of human rights is being called into question. There is an increasingly prominent debate emerging around business and human rights. This article has contributed to this debate by analyzing, from a South African perspective, the extent to which international and national human rights law is applicable to companies. It has for example, been highlighted that the corporate responsibility for human rights is very much binding given the impact of inter alia the Companies Act, the Constitution and International Law. Furthermore, the article has defined the scope of the corporate responsibility for human rights. It has been submitted, borrowing from the wording of section 7 of the Constitution that the corporate obligation for human rights should entail that companies respect, protect, promote and fulfil human rights. However, the primary responsibility for the realisation of human rights, remains with the State and is not diminished.

\section{References}

Benade, M. L., J. J. Henning, J. J. Du Plessis, P. A. Delport, L. De Koker \& J. Pretorius (2008). Entrepreneurial Law. Special ed. Durban: LexisNexis.

Davies, D., F. Cassim, W. Geach, T. Mongalo, D. Butler, A. Loubser, L. Coetzee \& D. Burdette (2010). Companies and Other Business Structures in South Africa. Southern Africa: Oxford University Press.

Chirwa, D.M "The Long March to Binding Obligations of Transnational Corporations in International Human Rights Law" SAJHR 2006(20): 84-85.

Esser, I. (2005). 'The Enlightened-Shareholder-Value Approach Versus Pluralism in the Management of Companies.' Obiter 26(3): 719725. 
Esser, I. \& J.J. Du Plessis (2007). 'The Stakeholder Debate and Directors' Fiduciary Duties.' South African Mercantile Law Journal 19: 346-363.

Hassim, A., M. Heywood \& J. Berger (2007). Health and Democracy. Cape Town: Siber Ink.

Havenga, M. (2005). 'Regulating Directors' Duties and South African Company Law Reform.' Obiter 26(3): 609-621.

Henkin L, "The Universal Declaration at 50 and the Challenge of Global Markets," (1999) 25(1) Brooklyn Journal of International Law 25.

Nivarthi S, Quazi A and Saleh A, "Corporate Social Responsibility and Human Rights: A Conceptual Framework" accessed 10 January 2013 available at http://anzmac.org/conference/2011/Papers\%20by\%20Presenting\%20Author/Quazi,\%20Alii\%20Paper\%20527 .pdf.

Paust J.J, "Human Rights Responsibilities of Private Corporations" (2002) Vanderbilt Journal of Transnational Law vol. 35, 801, 802.

Toebes, B. (1999). 'Towards an Improved Understanding of the International Human Right to Health.' Human Rights Quarterly 21: 661 679 .

Shandu, S. (2005). 'Shareholders' Interests versus Social Demands: Incongruous Agendas.' Obiter 26(1): 87-99.

Twinomugisha, B. K. (2008). 'Implications of the TRIPS Agreement for the Protection of the Right of Access to Medicines in Uganda,' Malawi Law Journal 2(2): 253-278.

Sherman J.f and Pitts C, "Human Corporate Accountability Guide: From Law to Norms Value" available at http://uww.hks.harvard.edu /m-rcbg/CSRI/publications/workingpaper_51_sherman_pitts.pdf, accessed on 25 February 2013.

Williams C.A \& Conley J.M, "Corporate Social Responsibility in the International Context: Is There an Emerging Fiduciary Duty to Consider Human Rights?" (2005) 74 University of Cincinnati Law Review 75. 